\title{
Role of Different Abiotic Factors Influencing Fluctuations of Fruit and Shoot Infestation Caused by Earias vittella on Okra (Abelmoschus esculentus L.)
}

\author{
G. Srasvan Kumar ${ }^{1 *}$, S.V.S. Raju ${ }^{1}$ and Swathi Yadav Kattula ${ }^{2}$ \\ ${ }^{1}$ Department of Entomology and Agricultural Zoology, IAS, BHU, Varanasi-221005, India \\ ${ }^{2}$ NIPHM, Rajendranagar, Hyderabad-500030, India \\ *Corresponding author
}

\begin{tabular}{|c|c|}
\hline & A B S T R A C T \\
\hline $\begin{array}{l}\text { Earias vittella, } \\
\text { Abelmoschus } \\
\text { esculentus, } \\
\text { Shoot and fruit } \\
\text { infestation. }\end{array}$ & \multirow{3}{*}{$\begin{array}{l}\text { Role of different abiotic factors on the temporal fluctuations of shoot and fruit infestation } \\
\text { by Earias vittella on okra crop were studied under field conditions at Vegetable Research } \\
\text { Farm, Banaras Hind University, Varanasi during Kharif season } 2014-15 \text { and } 2015-16 \text {. } \\
\text { Shoot infestation was observed during } 37^{\text {th }} \mathrm{SW} \text { (one month after sowing) where as fruit } \\
\text { infestation was observed during } 39^{\text {th }} \mathrm{SW} \text { ( } 6 \text { weeks after sowing). The maximum shoot } \\
\text { infestation has been observed at } 40^{\text {th }} \mathrm{SW} \text { while fruit infestation was maximum at } 42^{\text {nd }} \mathrm{S} \text {.W. } \\
\text { Thereafter, fruit infestation was gradually declined but persisted up to third week of } \\
\text { November. Further, shoot infestation found to have significant positive correlation with } \\
\text { morning R.H. during } 2014-15 \text { cropping season and maximum temperature during } 2015-16 \text {. } \\
\text { Other weather parameters did not significantly influence the shoot borer damage. Further, } \\
\text { weather parameters did not significantly influence the fruit damage by the borer during } \\
\text { both the years. }\end{array}$} \\
\hline Article Info & \\
\hline $\begin{array}{l}\text { Accepted: } \\
29 \text { May } 2017 \\
\text { Available Online: } \\
\text { 10 June } 2017\end{array}$ & \\
\hline
\end{tabular}

\section{Introduction}

Vegetables contribute as an important constitute of our food supplying vitamins, carbohydrates and minerals needed for a balanced diet. Their value is important especially in under developed and developing countries like India, where malnutrition abounds (Randhawa, 1974 and Khan et al., 2001).

In India vegetables are cultivated in an area of 9541 ' 000 ha with production of $1,68,300$ '000 MT and productivity of 17.3 MT ha ${ }^{-1}$. West Bengal occupies first place in area and production of vegetables followed by Uttar Pradesh, while productivity was highest in Tamilnadu (30 MT/ha) and U.P occupies $5^{\text {th }}$ place (21.6 MT ha $\left.{ }^{-1}\right)$ in productivity during
2015-16 (Indian Horticulture Database, 201516).

In India okra is being cultivated in an area of 507 ' 000 ha, with production of 5853 ' 000 MT, productivity of $11.5 \mathrm{MT} \mathrm{ha}^{-1}$ during 2015-16. In okra production West Bengal occupies the $1^{\text {st }}$ place ( $877^{\prime}$ '000 MT) followed by Bihar (783.54 '000 MT) and U.P occupies the $13^{\text {th }}$ place (148.64 ' 000 MT). Okra shares $5.9 \%$ in total vegetable area and $3.9 \%$ of total vegetable production in India (Indian Horticulture Database, 2015-16).

Okra, commonly known as "Bhendi" or "Ladies finger", is a native of tropical and subtropical Africa (Purseglove, 1984). It has 
been grown in the Mediterranean region as well as in the tropical and sub tropical regions of the world (Alam and Hossain, 2008). 'Okra' is fat and cholesterol free, very low in sodium, low in calories, and good source of vitamin $\mathrm{A}$, vitamin $\mathrm{C}$, vitamin $\mathrm{B} 6$ and of the thiamin. Okra green fruits contain water $(88 \%)$, carbohydrate $(7.7 \%)$, protein $(2.2 \%)$, calcium $(0.09 \%)$, phosphorus $(0.04 \%)$, iron (0.0051\%), vitamin A-58 IU, vitamin B- 63 IU and vitamin C $16 \mathrm{mg} / 100 \mathrm{~g}$ (Baloch et al., 1990).

The crop, however, is vulnerable to attack of important insect pests, among which fruit borer (Earias vittella Fabricius) is the most important pest causing direct damage to marketable fruits. It alone is reported to cause 57.1 per cent fruit infestation and 54.04 per cent net yield loss in okra (Chaudhary and Dadheech, 1989). Earias spp. are distinguished from other pests of okra by their marked tendency for stem boring. The larvae enter the terminal bud of vegetable shoot and channel down from the growing point. Severe attack, results in the wilting of top leaves and collapsing of the main stem. The larvae also bore into the flower buds, flowers and fruits of the crop. According to an estimate this pest can cause $36-90 \%$ loss in fruit yield of okra (Misra et al., 2002).

There are many abiotic factors that favour the growth, development and reproduction of various insect pests including $E$. vittella, thus limiting the production of okra thus limit the production of okra. Present studies have been conducted to record the incidence of shoot and fruit infestation during okra cropping season in accordance with seasonal fluctuations of various abiotic factors and the results thus obtained may be useful for formulating sustainable management practices of E. vittella on okra crop.

\section{Materials and Methods}

An area of $50 \mathrm{~m}^{2}$ was raised with local susceptible okra variety "VRO-6" to study the role of different abiotic factors on population fluctuation and fruit and shoot infestation caused by Earias vittella during Kharif season, 2014-15 and 2015-16 at Vegetable Research Farm, BHU, Varanasi. Okra seeds were sown at a distance of $60 \times 30 \mathrm{~cm}$. The experimental plot was kept unsprayed during the course of investigation and all agronomical practices were adopted to render suitable crop growth.

The shoot and fruit infestation was recorded in this un-protected plot of okra at 7 days interval from the occurrence or initiation of the pest infestation and was continued up to end of the crop. A total of 25 plants from five locations in the bulk plot @ 5 plants per each sampling area were selected and tagged for recording the observations on per cent shoot and fruit infestation. Total number of shoots along with the infested ones were counted and expressed as per cent shoot infestation at different sampling dates. During each picking carried out at weekly intervals, per cent fruit infestation was determined by counting total number of fruits along with the infested ones.

Per cent shoot infestation $=$

$$
\frac{\text { Number of damaged shoots }}{\text { Total number of shoots }} X 100
$$

Per cent fruit infestation $=$

$\frac{\text { Number of damaged fruits }}{\text { Total number of fruits }} X 100$

Weather data has been collected from the metrological observatory available at Agriculture Research Farm, Institute of Agricultural Sciences, BHU, Varanasi and correlated with the per cent shoot and fruit infestation. Among weather parameters, relative humidity, temperature, rainfall and 
sunshine hours were considered for correlating with the occurrence of the per cent shoot and fruit infestation of okra. To work out the relationship between the occurrence of the per cent shoot and fruit infestation of okra and the weather parameters, simple correlation method suggested by Pearson (1896) was adopted.

\section{Results and Discussion}

\section{Impact of abiotic factors on the} fluctuations of shoot infestation

The incidence and severity shoot infestation caused by $E$. vittella on okra crop along with meteorological observations during Kharif season 2014-15 has been presented in table 1 and figure 1 . The data showed that the shoot infestation by $E$. vittella first appeared one month after sowing i.e. $37^{\text {th }} \mathrm{S} . \mathrm{W}$ with mean per cent infestation of 5.00. Thereafter, shoot infestation was gradually raised and attained the peak $(23.33 \%)$ during $40^{\text {th }}$ S.W i.e., $1^{\text {st }}$ week of October, after that the population gradually declined and disappeared after 42 S.W.

The corresponding meterological parameters during peak shoot infestation were observed as maximum temperature $32.20{ }^{\circ} \mathrm{C}$, minimum temperature $24.20{ }^{0} \mathrm{C}$, morning R.H. $91.00 \%$, evening R.H. $64.00 \%$ and sunshine hours 6.30 hours and there was no rainfall during this period.

The simple correlation was worked out between weather factors and infestation of shoot during Kharif season 2014-15 and presented in table 1 and figure 1 revealed that there was no significant impact of weather factors on shoot damage except one i.e. morning R.H. that exhibited a positive significant correlation with shoot infestation $(r=0.725)$.
During second season also the incidence of the pest on shoots was recorded at weekly interval throught the crop duration and based on data, the percentage was worked out. The data presented in table 2 and figure 2 indicated that during Kharif season 2015-16 the damage of E.vittella to shoots was observed from four weeks after sowing i.e. $37^{\text {th }} \mathrm{S} . \mathrm{W}$ ( $2^{\text {nd }}$ week of September) to $42^{\text {nd }} \mathrm{S} . \mathrm{W}$ $\left(3^{\text {rd }}\right.$ week of October). As high as $21.67 \%$ shoot infestation was recorded in $40^{\text {th }} \mathrm{S} . \mathrm{W}$. ( $1^{\text {st }}$ week of October).

It is also evident from the table 2 and figure 2 that, maximum temperature $(r=0.649)$ had significant positive influence on the infestation of shoot borer during Kharif season 2015-16 while other factors had nonsignificant impact.

Mandal et al., (2006) and Zala et al., (1999) reported the activity of shoot borer in the field at four weeks after sowing. The present results were also found to be in close association with results obtained by Shukla et al., (1997) who reported that, initial shoot infestation occurred 3 weeks after sowing. These results are more or less similar with earlier findings made by Chandra and Singh (2012) who reported that the peak mean per cent shoot infestation was observed as $20.20 \%$.

Mandal et al., (2006) and Aziz et al., (2009) while working out the influence of weather parameters on population fluctuations and subsequent degree of damage, reported that shoot infestation was significantly positively correlated with relative humidity and maximum temperature, respectively. The present results are in close accordance with Aziz et al., (2011) who observed that shoot infestation exhibited a negative correlation with rainfall. 
Table.1 Impact of abiotic factors on seasonal incidence of shoot infestation on okra during 2014-15

\begin{tabular}{|c|c|c|c|c|c|c|c|c|c|c|}
\hline \multirow[t]{2}{*}{ S.W } & \multirow[t]{2}{*}{ Month and Date } & \multicolumn{2}{|c|}{$\begin{array}{c}\text { Temperature } \\
\left({ }^{0} \mathrm{C}\right)\end{array}$} & \multicolumn{3}{|c|}{$\begin{array}{c}\text { Relative Humidity } \\
(\%)\end{array}$} & \multirow[t]{2}{*}{$\begin{array}{c}\text { Rainfall } \\
\text { (mm) }\end{array}$} & \multirow[t]{2}{*}{$\begin{array}{l}\text { Sunshine } \\
\text { (Hours) }\end{array}$} & \multicolumn{2}{|c|}{$\begin{array}{l}\text { Average* per cent } \\
\text { infestation }\end{array}$} \\
\hline & & Max. & Min. & Morn. & Even. & Avg. & & & Shoot & Fruit \\
\hline 35 & Aug 27-Sep 02 & 33.00 & 27.10 & 84.00 & 71.00 & 77.50 & 6.50 & 6.00 & 0.00 & 0.00 \\
\hline 36 & Sep 03-09 & 32.70 & 26.40 & 85.00 & 69.00 & 77.00 & 34.90 & 5.30 & 0.00 & 0.00 \\
\hline 37 & Sep 10-16 & 31.90 & 25.80 & 86.00 & 80.00 & 83.00 & 11.00 & 4.00 & 5.00 & 0.00 \\
\hline 38 & Sep 17-23 & 33.30 & 26.00 & 87.00 & 72.00 & 79.50 & 13.70 & 5.20 & 11.67 & 0.00 \\
\hline 39 & Sep 24-30 & 33.40 & 24.30 & 90.00 & 56.00 & 73.00 & 2.10 & 8.40 & 16.67 & 7.58 \\
\hline 40 & Oct 01-07 & 32.20 & 24.20 & 91.00 & 64.00 & 77.50 & 0.00 & 6.30 & 23.33 & 11.73 \\
\hline 41 & Oct $08-14$ & 31.20 & 24.00 & 88.00 & 68.00 & 78.00 & 50.70 & 6.10 & 15.00 & 15.34 \\
\hline 42 & Oct $15-21$ & 29.80 & 19.80 & 88.00 & 69.00 & 78.50 & 0.00 & 7.20 & 11.67 & 26.84 \\
\hline 43 & Oct $22-28$ & 29.80 & 19.20 & 83.00 & 58.00 & 70.50 & 6.20 & 6.80 & 6.67 & 22.05 \\
\hline 44 & Oct 29-Nov 04 & 30.40 & 18.00 & 85.00 & 41.00 & 63.00 & 0.00 & 6.80 & 0.00 & 18.02 \\
\hline 45 & Nov $05-11$ & 31.40 & 16.30 & 86.00 & 39.00 & 62.50 & 0.00 & 6.80 & 0.00 & 14.63 \\
\hline 46 & Nov12-18 & 27.50 & 13.60 & 83.00 & 37.00 & 60.00 & 0.00 & 5.40 & 0.00 & 6.28 \\
\hline \multirow{7}{*}{\multicolumn{6}{|c|}{ Correlation coefficient (r) }} & \multicolumn{3}{|c|}{ Maximum Temperature (0C) } & 0.381 & -0.18 \\
\hline & & & & & & \multicolumn{3}{|c|}{ Minimum Temperature (0C) } & 0.595 & 0.140 \\
\hline & & & & & & \multicolumn{3}{|c|}{ Morning Relative Humidity (\%) } & $0.725^{*}$ & 0.079 \\
\hline & & & & & & \multicolumn{3}{|c|}{ Evening Relative Humidity (\%) } & 0.555 & 0.534 \\
\hline & & & & & & \multicolumn{3}{|c|}{ Average Relative Humidity (\%) } & 0.628 & 0.480 \\
\hline & & & & & & \multicolumn{3}{|c|}{ Rainfall (mm) } & -0.327 & -0.56 \\
\hline & & & & & & \multicolumn{3}{|c|}{ Sunshine (Hours) } & 0.365 & -0.34 \\
\hline
\end{tabular}


Table.2 Impact of abiotic factors on seasonal incidence of shoot infestation on okra during 2015-16

\begin{tabular}{|c|c|c|c|c|c|c|c|c|c|c|}
\hline \multirow[t]{2}{*}{ S.W } & \multirow[t]{2}{*}{ Month and Date } & \multicolumn{2}{|c|}{$\begin{array}{l}\text { Temperature } \\
\left({ }^{0} \mathrm{C}\right)\end{array}$} & \multicolumn{3}{|c|}{$\begin{array}{c}\text { Relative Humidity } \\
(\%)\end{array}$} & \multirow[t]{2}{*}{$\begin{array}{l}\text { Rainfall } \\
\text { (mm) }\end{array}$} & \multirow[t]{2}{*}{$\begin{array}{l}\text { Sunshine } \\
\text { (Hours) }\end{array}$} & \multicolumn{2}{|c|}{$\begin{array}{l}\text { Average* per cent } \\
\text { infestation }\end{array}$} \\
\hline & & Max. & Min. & Morn. & Even. & Avg. & & & Shoot & Fruit \\
\hline 35 & Aug 27-Sep 02 & 33.40 & 26.70 & 83.00 & 52.00 & 67.50 & 42.20 & 4.50 & 0.00 & 0.00 \\
\hline 36 & Sep 03-09 & 33.50 & 26.30 & 79.00 & 59.00 & 69.00 & 0.00 & 8.80 & 0.00 & 0.00 \\
\hline 37 & Sep 10-16 & 24.60 & 27.50 & 80.00 & 64.00 & 72.00 & 0.00 & 8.60 & 6.67 & 0.00 \\
\hline 38 & Sep 17-23 & 31.10 & 26.90 & 82.00 & 59.00 & 70.50 & 11.90 & 6.90 & 11.67 & 0.00 \\
\hline 39 & Sep 24-30 & 33.30 & 22.00 & 89.00 & 54.00 & 71.50 & 0.00 & 9.00 & 15.00 & 7.15 \\
\hline 40 & Oct $01-07$ & 34.00 & 22.80 & 90.00 & 66.00 & 78.00 & 0.00 & 8.80 & 21.67 & 10.68 \\
\hline 41 & Oct $08-14$ & 34.60 & 23.80 & 93.00 & 82.00 & 87.50 & 0.00 & 7.30 & 16.67 & 18.62 \\
\hline 42 & Oct $15-21$ & 33.00 & 21.80 & 88.00 & 51.00 & 69.50 & 0.00 & 8.00 & 13.33 & 26.85 \\
\hline 43 & Oct $22-28$ & 32.10 & 19.00 & 80.00 & 56.00 & 68.00 & 0.00 & 8.30 & 6.67 & 21.14 \\
\hline 44 & Oct 29-Nov 04 & 30.60 & 16.60 & 87.00 & 74.00 & 80.50 & 23.00 & 5.20 & 0.00 & 16.36 \\
\hline 45 & Nov 05-11 & 28.00 & 18.60 & 89.00 & 49.00 & 69.00 & 0.00 & 5.70 & 0.00 & 12.14 \\
\hline 46 & Nov12-18 & 30.40 & 16.60 & 86.00 & 40.00 & 63.00 & 0.00 & 7.60 & 0.00 & 5.42 \\
\hline \multirow{7}{*}{\multicolumn{6}{|c|}{ Correlation coefficient (r) }} & \multicolumn{3}{|c|}{ Maximum Temperature $\left({ }^{0} \mathrm{C}\right)$} & $0.649 *$ & 0.495 \\
\hline & & & & & & \multicolumn{3}{|c|}{ Minimum Temperature $\left({ }^{0} \mathrm{C}\right)$} & 0.591 & -0.457 \\
\hline & & & & & & \multicolumn{3}{|c|}{ Morning Relative Humidity (\%) } & 0.366 & 0.342 \\
\hline & & & & & & \multicolumn{3}{|c|}{ Evening Relative Humidity (\%) } & 0.377 & 0.127 \\
\hline & & & & & & \multicolumn{3}{|c|}{ Average Relative Humidity (\%) } & 0.439 & 0.217 \\
\hline & & & & & & \multicolumn{3}{|c|}{ Rainfall (mm) } & -0.334 & -0.058 \\
\hline & & & & & & \multicolumn{3}{|c|}{ Sunshine (Hours) } & 0.626 & -0.143 \\
\hline
\end{tabular}


Figure.1 Impact of abiotic factors on seasonal incidence of shoot and fruit infestation (\%) on okra during 2014-15

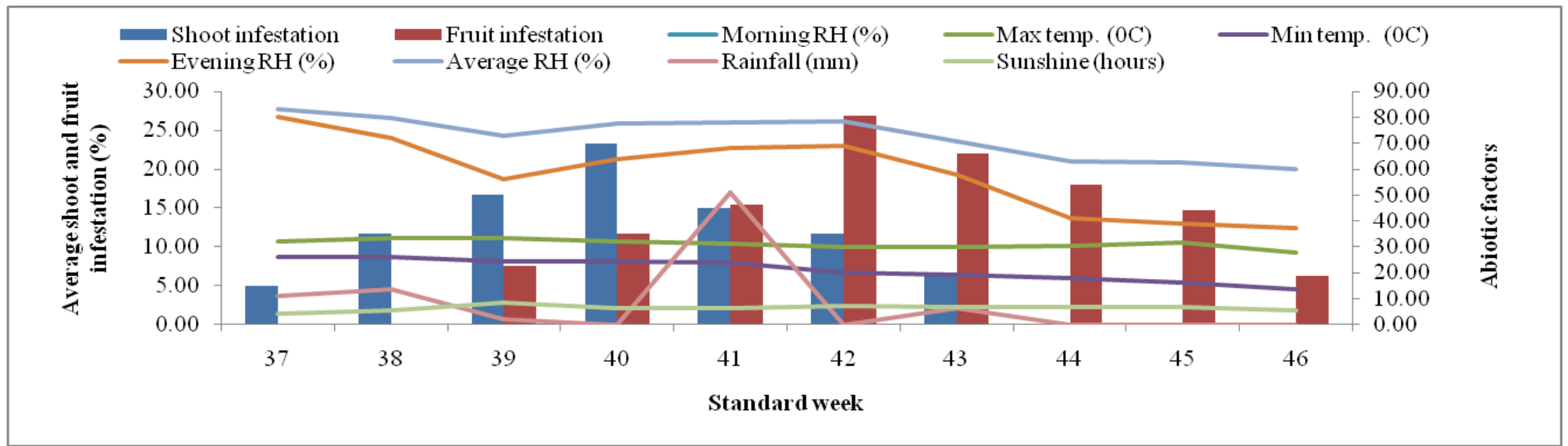

Figure.2 Impact of abiotic factors on seasonal incidence of shoot and fruit infestation (\%) on okra during 2015-16

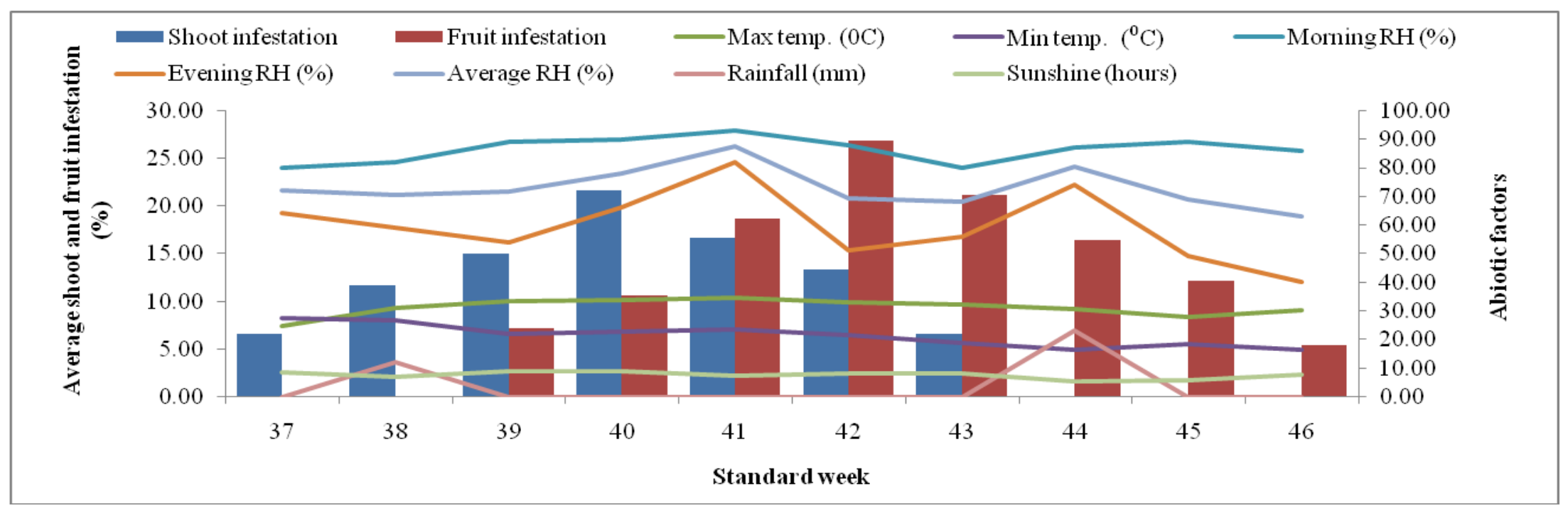




\section{Impact of abiotic factors on the severity of fruit infestation}

During 2014-15 the occurrence and intensity of fruit infestation observed was presented in table 1 and figure 1 which revealed that the damage of fruit borer started from $39^{\text {th }}$ S.W (6 weeks after sowing) lasted till end of crop season i.e. $46^{\text {th }}$ S.W ( $3^{\text {rd }}$ week of November). The peak fruit infestation (26.84\%) was reported during $42^{\text {nd }}$ S.W $\left(3^{\text {rd }}\right.$ week of October). Thereafter the fruit infestation gradually declined and attained very less infestation at $46^{\text {th }}$ S.W. The maximum temperature, minimum temperature, morning R.H., evening R.H., sunshine hours during peak fruit infestation were recorded to be $29.80^{\circ} \mathrm{C}, 19.80^{\circ} \mathrm{C}, 88.00 \%, 69.00 \%$ and 7.20 hrs, respectively. There was no rainfall during peak infestation. The simple correlation was worked out between weather parameters and fruit infestation during Kharif season 2014-15 presented in table 1 and figure 1 revealed that there was no significant impact of weather parameters on fruit infestation.

During second year experimentation (201516) also fruit infestation appeared six weeks after sowing $\left(39^{\text {th }}\right.$ S.W $)$ with a mean per cent infestation as $7.15 \%$. The peak fruit infestation was recorded during $42^{\text {nd }} \mathrm{S} . \mathrm{W}\left(3^{\text {rd }}\right.$ week of October) with a mean per cent infestation as $26.85 \%$, during this time, the maximum temperature, minimum temperature, morning R.H., Evening R.H., rainfall and sunshine hours recorded as 33.00 ${ }^{0} \mathrm{C}, 21.80{ }^{\circ} \mathrm{C}, 88.00 \%, 51.00 \%, 0.00 \mathrm{~mm}, 8.00$ hrs respectively. Thereafter the fruit infestation gradually declined up to end of crop i.e. $3^{\text {rd }}$ week of November. The effect of weather parameters on fruit infestation caused by E.vittella presented in table 2 and figure 2 that maximum temperature $(\mathrm{r}=0.495)$, morning R.H. $(r=0.342)$, evening R.H. $(r=$ $0.127)$ and average R.H. $(r=0.217)$ had nonsignificant, positive effect while minimum temperature $(\mathrm{r}=-0.457)$, rainfall $(\mathrm{r}=-0.058)$ and sunshine hours $(\mathrm{r}=-0.143)$ had nonsignificant but negative impact with fruit infestation.

The present findings were in partial agreement with those of Yadav et al., (2007) and Singh et al. (2015) who reported that fruit infestation commenced on five weeks old crop. Singh et al., (2015) also reported that fruit infestation prevail in field up to nine weeks old crop, these results are also nearly similar with the present findings. The present results are also corroborated with the results of Pareek et al., (2001) who reported that fruit infestation started in the month of September and peak infestation was observed in third week of October. The present results are in close association with Singh et al., (2015) and Nath et al., (2011) who reported that temperature and related humidity exhibited non-significant and positive correlation with fruit infestation. Further Kumar and Urs (1988) reported a negative non-significant correlation between rain fall and fruit infestation.

\section{References}

Alam, A. K. M. A and Hossain, M. M. 2008. Variability of different growth contributing parameters of some okra (Abelmoschus Esculentus L.) accessions and their interrelation effects on yield. Journal of Agriculture \& Rural Development. 6: 25-35.

Anonymous, 2015-16. Indian Horticulture Database $1^{\text {st }}$ estimate, Chief Editor Mamta Saxena, Advisor (Horticulture), Dept. of Agri. \& Coop.

Aziz, M. A., Mansoor-ul-Hasan and Amjad Ali. 2011. Impact of abiotic factors on incidence of fruit and shoot infestation of spotted bollworms Earias spp. on okra (Abelmoschus esculentusL.). Pakistan Journal of Zoology. 43(5): 863868. 
Aziz. M. A., Mansoor ul Hasan, Jamshaid Iqbal and Amjad Ali, 2009. Role of different weather factors on fluctuation of fruit and shoot infestation of Spotted Bollworms, Earias spp. on Okra (Abelmoschus esculentus L.), IJAVMS. Vol. 3 Issue 2: 64-72.

Baloch, A. F., Qayyum, S. M and Baloch, M. A. 1990. Growth and yield performance of okra (Abelmoschus esculentus L) cultivars. Gomal University Journal of Research.10: 191.

Chandra, M and Singh, R. S. 2012. Pest complex of Okra and population dynamics under Bundelkhand region, Uttar Pradesh. Annals of Plant Protection Sciences. 20(2):314- 317.

Chaudhary, H. R. and L. N. Dadheech (1989). Incidence of insects attacking okra and avoidable losses caused by them. Ann. Arid zone, 28 (3/4): 305-307.

Khan, M. A., Reddy J. D and Rao, S. V.2001.Efficacy of selected insecticides against pest complex in Okra, Abelmoschus esculentus Linn.Pestology. 25(9): 44-47.

Kumar, K. K and Urs, K.C.D. 1988. Population fluctuation of Earias vittella (Fab.) on okra in relation to abiotic factors.Indian $J$. Pl. Prot. 16(2): 132-142.

Mandal, S. K., Abdus Sattar., Sah, S. B and Gupta, S. C. 2006. Prediction of okra shoot and fruit borer (Earias vitella Fab.) incidence using weather variables at Pusa, Bihar. International Journal of Agricultural Sciences. 2(2): 467-469.

Misra, H. P., D. D. Dash and D. Mahapatra (2002). Efficacy of some insecticides against okra fruit borer, Earias spp. And leafroller, Sylepta derogata Fab. Ann. Pl. Prot. Sci., 10(1): 51-54.

Nath Lok., Prasad, C. S., Tiwari, G. N and Amit Kumar. 2011. Impact of weather parameters on major insect pests of okra prevailing western Uttar Pradesh. Vegetos, 24(2): 152-156.

Pareek, B.L., Kumawat, R.L and Patni, S.K. 2001.Effect of abiotic factors on incidence of okra insect pest in semi arid condition. Proceeding of National conference on Plant Protection. New horizons in the Millenium, Feb. 23-25, Udaipur, pp:1-8.

Pearson K. Mathematical contributions to the theory of evolution. III. Regression, heredity and panmixia. Phil Trans R Soc Lond Series A 1896; 187:253-318.

Randhawa, G.S. 1974.Horticulture ; Importance of pest control. Pesticides Annual, pp. 8587.

Shukla A., Pathak, S. C and Agrawal, R. K. 1997.Seasonal incidence of okra shoot and fruit borer Eariasvitella (Fab.) and effect of temperature on its infestation level.Advances in Plant Sciences. 10(1): 169-172.

Singh H. P., Vijaya V. Bajad and Chamroy, T. 2015. Seasonal incidence and field efficacy of insecticides against shoot and fruit borer, Earias vittella (Fab.) on okra (Abelmoschus esculentus 1.), Plant Archives.Vol. 15 No. 1, pp. 389-392.

Zala, S. P., Patel, J. R and Patel, N. C. 1999. Impact of weather on magnitude of Earias vittella infesting okra.Indian Journal of Entomology. 61(4): 351-355.

\section{How to cite this article:}

Srasvan Kumar, G., S.V.S. Raju and Swathi Yadav Kattula. 2017. Role of Different Abiotic Factors Influencing Fluctuations of Fruit and Shoot Infestation Caused by Earias vittella on Okra (Abelmoschus esculentus L.). Int.J.Curr.Microbiol.App.Sci. 6(6): 2514-2521. doi: https://doi.org/10.20546/ijcmas.2017.606.299 